\title{
Introduction to Politeness and Impoliteness Research in Global Contexts
}

\author{
Miriam A. Locher ${ }^{1}$ and Tatiana V. Larina ${ }^{2}$ \\ ${ }^{1}$ University of Basel, Department of Languages and Literatures, Englisches Seminar \\ Nadelberg 6, 4051 Basel, Switzerland \\ ${ }^{2}$ RUDN University (Peoples' Friendship University of Russia) \\ 6 Miklukho-Maklaya str., 117198 Moscow, Russian Federation
}

\begin{abstract}
$\mathrm{Im} /$ politeness research has been a solid and growing research field in sociolinguistics, pragmatics and discourse analysis during the last four decades. The scientific interest in this topic is not accidental and may be explained by the general pragmatic turn of modern interdisciplinary linguistic studies which are not focused on language as an abstract system, but on its functioning in various contexts and types of interaction. Knowledge of the strategies and politeness mechanisms used in various social and cultural contexts promotes mutual understanding in communication. In this introduction to the special issue on im/politeness in global contexts we will briefly position the topic of im/politeness research, and highlight advancements in im/politeness theory, method and data. We then turn to a brief synopsis of each individual paper and highlight the theoretical and methodological contributions and innovations proposed by our authors. We end with a discussion of the results and a brief outlook on future research.
\end{abstract}

Key words: politeness, impoliteness, face, im/politeness theory

\section{For citation:}

Locher, Miriam A. and Larina, Tatiana V. (2019). Introduction to politeness and impoliteness research in global contexts. Russian Journal of Linguistics, 23 (4), 873 - 903. doi: 10.22363/2312-91822019-23-4-873-903.

\section{Введение в исследование вежливости и невежливости в глобальном контексте}

\author{
М. Лохэр ${ }^{1}$, Т.В. Ларина ${ }^{2}$ \\ ${ }^{1}$ Базельский университет, Базель, Швейцария \\ Nadelberg 6, 4051 Basel, Switzerland \\ ${ }^{2}$ Российский университет дружбы народов (РУДН) \\ 117198, Москва, ул. Миклухо-Маклая 6
}

\begin{abstract}
Аннотация
В течение последних четырех десятилетий исследование вежливости, а затем и невежливости, составляет значимую область прагматики, дискурс-анализа и социолингвистики. Научный интерес к этой теме не случаен, он обусловлен общей антропоцентрической парадигмой современных
\end{abstract}


междисциплинарных лингвистических исследований, которые сосредоточены не на языке как абстрактной системе, а на его функционировании в различных контекстах и типах взаимодействия. Знание стратегий и механизмов вежливости, используемых в различных социальных и культурных контекстах, способствует взаимопониманию в общении. В нашей вводной статье к специальному выпуску о вежливости и невежливости в глобальном контексте мы кратко остановимся на развитии теории не/вежливости, расширении методологии и материала исследований. Затем обратимся к каждой статье и определим теоретический и методологический вклад, а также те элементы новизны, предложенные нашими авторами, которые расширяют имеющиеся представления о не/вежливости. В заключение обсудим полученные результаты и наметим перспективы дальнейших исследований.

Ключевые слова: вежливость, невежливость, лицо, теория вежливости и невежливости

\section{Для цитирования:}

Locher, Miriam A. and Larina, Tatiana V. (2019). Introduction to politeness and impoliteness research in global contexts. Russian Journal of Linguistics, 23 (4), 873-903. doi: 10.22363/2312-91822019-23-4-873-903.

\section{Introduction}

In 2014 the Russian Journal of Linguistics dedicated a special issue to Geoffrey Leech and gave im/politeness studies center stage. The volume brought a large number of scholars together who added their voices to other research outlets such as the Journal of Politeness Research, Pragmatics or the Journal of Pragmatics, to name just three of the prominent journals within pragmatics where politeness scholars find their readership. Five years later, we again turn to this topic and pursue im/politeness research in "global contexts". When we issued the call for the present volume, we thought of global contexts in two ways. On the one hand, we hoped that our contributors would continue the trend to work on a variety of different languages and contexts in order to enhance our understanding beyond languages like English or Japanese, two languages which have received much attention to date. We have achieved this aim in that our authors work on a wide variety of languages, here presented in alphabetical order: Arabic, English, Greek, Korean, Russian, Spanish and Mandarin Chinese, as spoken in Taiwan. On the other hand, we also encouraged submissions which enhance our theoretical and methodological understanding of im/politeness phenomena in global contexts ${ }^{1}$. The contributions could achieve this either by addressing a cross-cultural and/or cross-linguistic perspective or by adding their insights to previous research on comparable discourse contexts as found in different languages and cultures. In what follows, we will first briefly position the topic of im/politeness research to contextualize the contributions to the special issue. We then turn to a brief synopsis of each individual paper and highlight the theoretical and methodological contributions and innovations proposed by our authors. We end with a discussion of the results and a brief outlook on future research.

${ }^{1}$ Note that we are not concerned with the impact of globalisation, as discussed by Sifianou \& Garcés-Conejos Blitvich (2018) in their special issue in the Journal of Pragmatics. 


\section{Advancements in im/politeness theory, method and data}

Ever since the early surge of politeness research epitomized by the work of Lakoff (1973), Brown and Levinson $(1978,1987)$ and Leech (1983, see also 2014), politeness research has been a solid and growing research field in pragmatics ${ }^{2}$, discourse analysis and sociolinguistics and there is no sign of decline in interest. While the early work on politeness combined a Gricean understanding of the creation of meaning with speech act analysis and was thus interested in pragmatic variation on the utterance level, the field has expanded considerably in the last decades. In earlier overviews, Locher (2014, 2018) reported on several areas of expansion, which can be subsumed in two blocks. The first cluster is about theoretical and methodological advancements, while the second cluster concerns the type and scope of data as well as the range of linguistic phenomena studied. For comprehensive and recent overviews, the reader is referred to the Palgrave Handbook of Linguistic (Im)politeness (Culpeper et al. 2017). In this brief introduction to the field, we can only highlight a number of pertinent issues.

Early research was particularly interested in discussing how mitigation achieves face protection of both the hearer and the speaker. This research typically worked on particular speech acts on the utterance level. As a consequence, mitigation was almost used synonymously with politeness. This was the case no matter whether the interactants themselves were thinking of their mitigation practices as acts of expressing politeness. In contrast, a lay understanding of politeness often associates politeness with prescribed rules in etiquette books, which include linguistic phenomena but also forms of comportment more generally, and is thus of a multi-modal nature and draws on different ideologies of proper comportment. This multi-modal aspect of politeness norms has been acknowledged by many scholars who include facial expression and gestures in their analysis (typically, qualitative discourse analysis and conversation analysis) and who are interested in uncovering the interplay between different norms, but multimodality has featured less in research that works with discourse production and completion tasks or corpus linguistics.

The difference between emic (lay) and etic (theoretical, scholarly) understanding of $\mathrm{im} /$ politeness has given rise to the discursive approach to im/politeness (see Eelen 2001). In fact, the most important contributions of the discursive turn were to remind us of the evaluative and situated nature of concepts such as impoliteness or politeness, the importance that emotions play in assessments and to argue for the link of identity construction with these processes of judging (e.g. Haugh et al. 2013, Linguistic Politeness Research Group 2011, Langlotz \& Locher 2017, Locher 2004, 2015, Locher and Watts $2005,2008)$. It is by now standard practice to combine etic and emic approaches in order to account for the interplay between the perspectives ${ }^{3}$. For example, while face-aggravating, face-maintaining and face-enhancing are etic concepts, they can be linked to particular emic assessments as impolite or rude in the analysis of particular interactions (see Locher 2015: 8, Haugh \& Chang, this volume, and Fernández-Amaya, this volume).

${ }^{2}$ We adopt a European definition of pragmatics which goes beyond the sentence level and includes the study of language in use from a social and cultural viewpoint (see Locher and Graham 2010: 1, Taavitsainen \& Jucker 2010).

${ }^{3}$ Garcés-Conejos Blitvich \& Sifianou (2019: 94) refer to this as the third wave of politeness research, which, we believe, was co-occurrent with the second wave rather than following it neatly. 
In general, the type of data that has been systematically researched over the last decades has been widened in scope. First, research into historical forms of politeness surface structures as well as the development of historical forms has thrived (e.g. Culpeper \& Kádár 2010, Jucker \& Kopaczyk 2017, Paternoster \& Fitzmaurice 2019, Rathmayr 2009). This research highlights how norms are negotiable and changeable and that linguistic politeness strategies have developed over time and are embedded in their cultural context and ideologies of conduct. Second, scholars became interested in impoliteness and rudeness effects as well and have moved away from focusing primarily on mitigation of face-threats. The scope of linguistic phenomena studied has thus been broadened to include face-aggravating behavior (e.g. Bousfield 2008, Bousfield \& Locher 2008, Culpeper 2011, specialized conferences such as LIAR - the linguistic impoliteness and rudeness conferences). Third, while there is still a strong branch which looks at individual speech acts on the utterance level, many studies work with longer stretches of talk and are interested in how relational meaning is negotiated over several turns in context (see Garcés-Conejos Blitvich \& Sifianou 2019: 94). Finally, the type of data studied nowadays is varied and includes naturally-occurring face-to-face oral data, multimodal computer-mediated data, and written data of all shades and forms (e.g. fictional and non-fictional). Not surprisingly, especially the study of computermediated data has gained particular momentum since the early 2000s in special issues, monographs, and many research articles (see also Parvaresh, this volume and below). In addition, scholars work with elicited data in its own right or to complement findings based on naturally-occurring data (e.g. interviews or discourse production and completion tasks).

From a theoretical point of view, this broadening in scope has important repercussions for theorizing im/politeness. The changeability and negotiability in expressing face concern reported from historical research means that we also have to revisit our understanding of what exactly is universal in politeness research. If it is not the surface realization, then it likely to be the capacity of human beings (model person in Brown and Levinson's 1987 framework) to recognize one's own and the addressee's face needs and to use language strategically for effect. In fact, much research effort has been invested into identifying culture specific features of understanding, perception and expression of politeness and the results also show changeability, negotiability and variability. As numerous cross-cultural studies have shown, while expressing politeness seems to be universal, how this is being done is in essence a culture specific phenomenon (e.g. Leech 2005, 2014). Ideas about what is polite and what is not might differ crossculturally (see Larina 2003, 2004, 2009, 2013, Rathmayr 2003, Sifianou 1992, Watts 2003 among others). The same act of communication (verbal or non-verbal) perceived as polite in one culture may be considered as inappropriate, impolite and even rude in another (Larina 2015: 197, see also Haugh and Chang, this volume) ${ }^{4}$. As a consequence, much research effort is invested in teasing apart how large scale ideologies as

${ }^{4}$ Watts (2003: 14) rightly claims that the lexemes polite and politeness and the terms matching them in other languages may vary in meaning and connotations associated with them (Watts 2003: 14). Depending on one's research question, this insight has methodological implications (see, for example, Locher 2012: 50 for the problematic idea of making an etic distinction between impoliteness and rudeness based on the English lexeme connotations, when studying other languages than English). 
well as norms developed in different contexts and on different levels (e.g. personal, cultural, situational and co-textual norms; Culpeper 2008: 30) inform and shape politeness. Knowing what effect a particular phrasing might have means that interlocutors are aware of the norms of a lingua-culture in its different levels and can exploit this knowledge to maintain, challenge/aggravate or enhance their own or their addressee's face. They do this in situ, i.e. they exploit the indexical force of their linguistic choices at the time and in their context. In doing so, there is an intricate interplay between societal ideologies, the norms of a particular community of practice and the activity types they activate and the actual indexicalities evoked by the interactants ${ }^{5}$.

In addition, the broadening of scope also sheds more light on the study of pragmatic variability in expressing different speech acts and in negotiating meaning in longer stretches of data in different contexts more generally. This is because this field has not just been a concern of im/politeness scholars (see Locher 2015 for elaboration on this point). The im/politeness research community has reached out to other fields and there are by now a number of theories and approaches that can cross-fertilize each other. Among them are Arundale's face-constituting theory (e.g. Arundale 2010, 2013), Spencer-Oatey's rapport management (Spencer-Oatey 2005, 2009), relational work in interpersonal pragmatics (Locher \& Watts 2005, 2008; Locher \& Graham 2010), Faircloughian genre and discourse inspired studies (Garcés-Conejos Blitvich 2010, Garcés-Conejos Blitvich \& Sifianou 2019), the impact of politeness on communicative styles (House 2006, Larina 2003, 2009, 2015), and research on identity construction (e.g. Bucholtz \& Hall 2005, 2008; Hall \& Bucholtz 2013). The latter is an especially promising research avenue since politeness judgements always also have repercussions on identity construction, which in its turn guides the way people interact (see GarcésConejos Blitvich 2009, Garcés-Conejos Blitvich \& Sifianou 2017, Larina et al. 2017a, Locher 2008).

In Parvaresh's (this volume) report on the 2019 meeting of the International Symposium of Politeness, these general trends are confirmed. Scholars convened to report on research about both politeness as well as impoliteness and they demonstrate an enriching mix of methodologies and theories. He reports that the study of im/politeness in historical data is going strong, that researching online data is still a hot issue, that the study of aggressive language helps to tease out the indexicality of relational messages, that conceptualising morality in addition to personal, cultural, situational and co-textual norms (Culpeper 2008: 30) has gained in importance, that research which takes the evaluative notion of im/politeness into account (Locher 2004) is continued, that notions of impoliteness and conflict are being elaborated on, that individual speech acts continue to be studied comparatively across lingua-cultures and on their own and, finally, that ethical considerations and risks involved in data collection was discussed numerous times. Overall, the research field is thus striving. In what follows, we will introduce the papers in this special issue which add their voices to this discussion.

5 Garcés-Conejos Blitvich and Sifianou (2019: 97) refer to this complex interplay as micro (style), meso (genre) and macro (discourse) and base their argumentation on Fairclough's (2003) insights. While they argue that concepts of community of practice and activity type cannot do the work of combining the meso with the macro level, we see no reason to discard these concepts and believe that the important work of linking these levels can be achieved through them. 


\section{Issues covered in the collection}

The collection presents nine original research papers. The first paper by Haugh and Chang focuses on the speech act of criticism from a cross-linguistic and cross-cultural perspective. Since the authors highlight the methodological challenges of an analysis of this kind, they set the scene for later papers concerning an approach to im/politeness in global contexts. This paper is followed by a theoretical paper presenting a metaanalysis of the changing role of indirectness in im/politeness studies by Terkourafi. The following three papers focus on different languages and explore these with different methodologies: Rhee employs a historical approach on Korean; Bragina and Sharonov use corpus linguistics and discourse analysis on Russian, and Vlasyan and Kozhukhova work with discourse production tasks on Russian. The papers thus demonstrate how we can gain insights about different languages, contexts and cultures with the help of a wide variety of different methodologies. This trajectory is continued in the remaining papers as well. However, the papers in the last group all introduce research on naturallyoccurring data derived from computer-mediated communication. $\mathrm{Im} /$ politeness in online contexts has intensively been worked on in the last two decades (for overviews see, e.g., Graham \& Hardaker 2017, Locher 2006, Locher et al. 2015). The papers in this volume continue the discussion of methodological and theoretical approaches and add insights into different languages and cultures in online practices. We will position these contributions one by one.

The starting point for this collection is a paper by Michael Haugh and Wei-Lin Melody Chang. They work with elicited data where informants meet for the first time. Their data sets consist of dyads in English recorded in Australia and dyads in Mandarin Chinese recorded in Taiwan. The focus of analysis are acts of criticism of the conversational partner. While much research in the past focused on comparing the linguistic realization of speech acts, the authors argue that an integrated sequential and indexical analysis will help us better understand not only cross-linguistic differences but also the different status of the content of the speech act and the indexical value of the speech act in the different cultures. They address the methodological challenge of approaching data as researchers who are part or are not part of the studied community, the implications of this presence/absence of membership for analysis and the consequences on theorizing $\mathrm{im} /$ politeness. Their paper works as an important reminder that the label "criticism" per se might have different connotations in different cultures and that only comparing linguistic form might fall short of a comprehensive analysis since the members themselves might have different interpretations of the speech act. This important insight is further elaborated on in Fernández-Amaya's (this volume) contribution on disagreement (see below).

Marina Terkourafi turns our attention to the role of linguistic indirectness in im/politeness studies in the light of processes of urbanization and globalization. While the use of indirectness has been associated with face-saving and has been described as a universally safe strategy (Brown \& Levinson 1987), Terkourafi offers an alternative interpretation. In doing so she combines im/politeness studies with network theory (Milroy 1987). She explains that ingroup knowledge is needed to interpret 
indirectness and therefore what Terkourafi terms accidental indirectness is only accessible to this ingroup. As a consequence, indirectness might become disfavored as a strategy. By presenting a meta-analysis of three studies in different linguistic and cultural contexts which offer a diachronic perspective on the use of indirectness (Morgan 1991 on the use of indirectness in a community of African-American women; He 2012 and others on complimenting in Chinese; Jucker 2012 on the development of English politeness), Terkourafi draws our attention to the hypothesis that the overall weakening of networks might be the reason for a potential increase in direct rather than indirect linguistic strategies. To explore this hypothesis further is of interest for im/politeness studies as it questions one of the pillars of im/politeness studies.

Seongha Rhee turns our attention to Korean, one of the most grammatically indexical languages with respect to politeness phenomena. In fact, "in Korean the speakeraddressee relationship is reflected in mandatory sentence-final verbal morphology" (Rhee \& Koo 2017: 101). In addition, there is a diverse pronoun system and a complex address term system, which comprises both kinship as well as terms derived from work hierarchies and seniority. Positioning his research in an understanding of 'emergent grammar' (Hopper 1987) and grammaticalization processes, Rhee explores in particular the development of the first and second person pronouns and their link to address terms from a historical perspective. In doing so, he is able to show how politeness considerations of defining one's place in society by expressing respect to others (+honorific) and displaying one's lower position with respect to others (+humiliative) is achieved through linguistic indexicals. This pronoun and address term system is highly dynamic and continuously develops in order to fulfil the expressive needs of the interactants. This development is steered by the pressure and challenge to choose adequate markers since choosing the wrong level or omitting the use of proper address terms might result in undesired pragmatic effects. Rhee argues that, just like words and phrases employed to avoid taboo lose their mitigating power over time, the pronouns change their power of indexing politeness and positioning through frequent use. As a consequence, "[+Honorific] terms are constantly innovated to upgrade the diminishing honorification effect and the first-person reference terms are constantly innovated to strengthen the [+Humiliative] meaning" (Rhee, this volume). This study demonstrates that the research community can gain much from broadening the scope of data to include a diachronic perspective. In showing that the pronoun politeness indexicals are dynamic over time, we are reminded of the dynamic nature of linguistic realisations of acts of positioning that express politeness concerns per $\mathrm{se}^{6}$. However, what seems to be stable is the need to express these differences in positioning and politeness.

Natalia Bragina and Igor Sharonov present a corpus linguistic analysis of over 200 naturally-occurring Russian dialogues from the Russian National Corpus that involve face-threatening and face-aggravating behavior. They focus in particular on instances

${ }^{6}$ Note that we do not wish to imply that "anything goes" and that everything is re-invented constantly from scratch (as some critics of the discursive approach have misunderstood). (Im)politeness indexicals take their power from norms that are shared by individuals. However, these very norms can change over time, as Rhee's paper has so convincingly demonstrated. For more elaboration on this point, see Locher (2012: 52). 
where a conversational partner reprimands an interlocutor for the perceived, inappropriate nature of a previous statement. The context of these interactions is everyday informal communication. The authors label these reprimands "pedagogical aggression" because of their corrective nature and their negative stance towards the addressee. Due to these features, the authors argue that these reprimands become impolite in turn and are set in contrast to responses which aim at neutralizing a previously perceived inappropriate contribution (which the authors call empathy strategy). The form that the contributions containing pedagogical aggression take are "1) a pseudo-question (rhetorical question or a question to the assumptions of an interlocutor), 2) mocking citations from the interlocutor's speech, [and] 3) rhymed pseudo-answers" (Bragina $\&$ Sharonov, this volume). In this article the authors focus on the third type. They show that this strategy is assessed by native speakers as impolite, but possible, since there is an unspoken presumption according to which aggressive-educational speech behavior is allowed against an interlocutor who made a communicative mistake in informal communication. There is a set of speech formulas in the Russian language for the realization of this strategy. In intimate contexts the use of rhymed pseudo-answers can sound humorous and not lead to conflict. However, the authors show that, in further communication, the interlocutors take care to explain and make amends for his or her attack against the addressee. In a conflictual dialogue, stereotypical pseudo-answer phrases are used to break off the contact with the interlocutor or to switch to another mode of communication. The authors' study convincingly shows that the strategy of pedagogical aggression becomes particularly noteworthy because it is contrasted with the empathy strategy. This finding highlights that the indexical power of politeness or impoliteness in situ is derived by processes of contrasting behavior with each other. This theoretical point links to insights on the discursive nature of im/politeness judgements, as proposed and developed by a number of scholars (e.g. Haugh et al. 2013, Linguistic Politeness Research Group 2011, Locher \& Watts 2005, 2008, 2015), and as further developed in this volume by Tzanne and Sifianou (see below).

Gayane Vlasyan and Irina Kozhukhova work on im/politeness in Russian by means of elicited data obtained through a discourse production test with 101 participants of three age groups: schoolchildren, university students and adults. The task was to issue an invitation in scenarios which differed according to age and social status of the interactants considering both symmetrical (informal context) and asymmetrical (formal context) relations. The respondents were supposed to invite (a) a friend/colleague and (b) a teacher/ boss to an event or a birthday party. The authors wanted to establish whether a difference is made in formal and informal contexts and how this reflects on a particular Russian understanding of the speech act invitation. They report that there are indeed differences in politeness strategies and linguistic means of expression in formal and informal contexts. Overall, however, there is a preference for issuing direct invitations, which correlates with the Russian style of communication in general (see Larina 2003, 2008, 2009, 2015). The results show that in symmetrical contexts in the groups of schoolchildren and students the most typical form of invitation is the imperative (literal translation: Girls, come to my place on Saturday to celebrate my birthday). In the group of adults as well as in all the three groups in formal (asymmetrical) context, it is the performative (I invite 
you to my birthday party). However, indirect invitations are not uncommon but they are less frequent and are not favored by any of the groups under the study. This finding is consistent with the idea that in Russian giving options while inviting "could be interpreted as evidence of the Speaker's insincerity, rather than a demonstration of respect for the Hearer's wants" (Leech \& Larina 2014: 15) and could be perceived negatively. Rather than hedging, the respondents of all three groups used many intensifiers both in informal and formal contexts (literal translation: You must come / Your presence is mandatory / Rejection is not accepted / I (we) really want to see you / I (we) will be very glad to see you). Thus the authors demonstrate that Russian inviters place high value on signaling the speaker's interests. The paper adds to our knowledge of the speech act of invitation since it analyses new data and argues that in Russian culture invitation appears not to be a face-threatening act. The authors support the idea that in Russian culture, which is of a collectivist type (Larina et al. 2017a,b), directness does not always violate principles of politeness and in many speech acts and contexts is expected and perceived positively. The findings also show that culture-specific differences in communication are not random but systematic and regular use of typical strategies leads to the formation of communicative features, the totality of which forms a communicative ethno-style (Larina 2015: 197).

As mentioned in the previous section, the research community has long recognized that politeness judgements are linked to norms of different types. Culpeper (2008: 30) speaks of personal, cultural, situational and co-textual norms that shape interaction. Kádár and Haugh (2013: 95), in turn, mention localised norms, "community of practice/organisational or other group-based norms," and societal/cultural norms. To gain access to and tease these norms apart is one of the challenges of $\mathrm{im} /$ politeness research. Angeliki Tzanne and Maria Sifianou take up this challenge and ask where and how researchers can gain an entry point into establishing what a community's particular lay conceptualizations of politeness and impoliteness are. In their research, they thus tackle the tricky question of how to discover norms, i.e. how to know what is perceived as (im)polite in a particular context as an analyst. Rather than studying interactions between participants or turning to etiquette books (both valid sources, of course), they argue that scholars can also gain much insight from looking at media coverage of $\mathrm{im} /$ politeness issues. They are therefore interested in meta-discussions in the public space, which point to a societal rather than individual understanding of impoliteness. Their data consists of two online articles on impoliteness in Greece written by one journalist, which were shared in the media and received reader comments. Analyzing the articles and the comments with the help of the concepts of discursive identity construction and van Dijk's (1998, 2006a, b) insights into ideological positive self-presentation and negative other-presentation, the authors show that impoliteness is not only perceived as a linguistic phenomenon but encompassed all kinds of behaviour in the public and private space, and that, crucially, the "solite' and 'impolite citizen"" are "co-constructed as binary opposites by the journalist and posters" (Tzanne and Sifianou, this volume). While such views are stereotypical to a certain extent, they reveal recurrent and pervasive lay understandings of im/politeness norms. The authors reveal that the ingroup of polite citizens are constructed as superior to the impolite 
outgroup and are differentiated along lines of power, knowledge, education, civilization and intelligence. The contribution thus demonstrates how insights from online metadiscussions can further our understanding of lay conceptualizations of im/politeness. Once more, the process of acts of contrasting is brought home. That the parameters of contrasting can easily shift, however, was shown in a comparable analysis by Locher and Luginbühl (2019). As in Tzanne and Sifianou's contribution, online newspaper articles and reader comments were analyzed. In this case, the triggering texts contrasted German politeness with Swiss (German) politeness norms. Interestingly, the Swiss speakers of German dialects were observed to construct a unified Swiss versus German politeness understanding, but have been observed to uphold a difference in dialectal norms when talking only about the Swiss. This is because there are many dialects in Switzerland but, apparently, for the process of comparison with an outgroup, this fact is simplified, and as a consequence different norms were constructed as well.

Najma Al Zidjaly's contribution adds yet another perspective to the im/politeness discussion. Her paper is entitled "Divine impoliteness: How Arabs negotiate Islamic moral order on Twitter" and is the result of engaging in a long-term online ethnography which observes Arab identity construction on social media. Al Zidjaly has demonstrated in numerous publications how the religious moral order imbues Arab identity construction and understanding of self (e.g. Al Zidjaly 2014, 2017, 2019). For this paper, the author chose to analyse one particular tweet which triggered many comments and kept the media spot light for a considerable time. This post discussed a well-known prayer that includes Muslims but excludes non-Muslims by omission from getting well (i.e. by not mentioning them). The tweet author questions the morality of this exclusivity/omission and invites discussion. Since questioning the Quran and the hadiths ("the reported sayings of the prophet of Islam documented in the authoritative books of Sahih Al-Bukhari and Sahih Al-Muslim", Al Zidjaly, this volume) is not allowed, the discussion is controversial from the beginning. As it turns out in the discussion of the participants, the prayer's wording is neither taken from the Quran nor the hadiths so that voicing different opinions and engaging in discussions of these opinions becomes possible. A recurrent strategy is what Al Zidjaly terms "divine impoliteness", i.e. commentators turn to and quote religious authoritative texts, which are aggressive towards others, in order to legitimize the face-loss of the omitted parties who are being excluded from prayers of getting well. In Al Zidjaly's view, these online discussions are evidence of a "shift in Islamic moral order", the discussion of which has become increasingly possible in online contexts. Since work on im/politeness in Arabic is only slowly increasing in number (e.g. Badarneh 2019, Farhat 2013, Labben 2018), this paper is particularly welcome as it highlights the complexity of different types of norms that intertwine in im/politeness considerations and particularly spotlights the religious moral order as an aspect that secular Western scholars might be less aware of.

Lucía Fernández-Amaya's contribution presents a case study of a naturallyoccurring WhatsApp conversation among family members, which took place during 14 hours in Spain and comprises over 9900 words. This close-knit group discusses the demonstration held in the context of International Women's Day, which took place on the same day. As it turns out, the family members hold diametrically opposed views 
on feminism and express these views in the WhatsApp chat. This results in prolonged arguments where people position and defend their own point of view as well as react to others' contributions. The linguistic focus of the study is thus the expression of disagreement and alignment and disaffiliation with each other. In a qualitative analysis of 427 instances of disagreement, Fernández-Amaya first establishes a typology of disagreements and then codes the established strategies systematically in order to arrive at the overall distribution of the strategies (giving opposite opinions and emotional or personal reasons are most frequent) and the distribution among the members of the family. In doing so, she is able to show how the family members differ in their preferences. In a second step, the contributors to the WhatsApp discussion were sent an electronic questionnaire and relevant passages to establish whether the directness of the disagreement and the often diametrically opposed positions expressed resulted in impoliteness judgements. Adding to research on disagreement and relational work, which reported that the expression of disagreement is often expected and not necessarily negatively marked (for an overview, see e.g., Angouri and Locher 2012), the author found that the family members did not consider the uttered face-threats to be severe or impolite. Instead, their close bond and family ties allowed them to express themselves without fear of damaging their relationships and some even evaluated the encountered disagreement in positive terms. Just as Haugh and Chang (in this volume) reminded us in their study of criticism in first encounters, the indexical value of a speech act as well as its realization have to be analyzed in context in order to make statements about their evaluative status with respect to im/politeness norms.

The final research contribution of the special issue and of the block on computermediated communication is written by María de la $\mathbf{O}$ Hernández-López, who works on naturally-occurring consumer reviews in English on the peer-to-peer business platform Airbnb. Similar to the work by Dayter and Rüdiger (2014), who worked on comments on Couchsurfing, Hernández-López also highlights how the reviewers engage in a delicate act when writing reviews. This is because both the host's as well as guest's public faces on the platform are at stake since both parties are being rated and their earning possibilities in case of the host and their acceptance rate as guest will be affected by the ratings. By analyzing 120 reviews, Hernández-López establishes three different emotional orientations: delighted/satisfied, ambivalent/neutral, and dissatisfied/disappointed. The established forms and distribution are then linked to a discussion of what norms prevail (following Locher and Watts 2005, 2008). The results point to a clear preference of being polite, while avoiding overtly being rude or offensive. Due to this positivity norm, however, what is not being said is also informative and implies dissatisfaction on this peer-to-peer business platform. Linguistically, messages leaning toward the negative pole of the cline are characterized through "a process of depersonalisation, with a tone based on formality and distancing from the host", while messages leaning towards the positive end of the cline are characterized through the use of enthusiastic and friendly vocabulary and content. Furthermore, with respect to this peer-to-peer business platform, Hernández-López shows how sociability is constructed as key for both the host's and the guest's behavior. Methodologically, the paper adds to our understanding of how the norms of a particular community can be studied. She established patterns of stance and content distribution and was then able to compare 
her results to similar (but not identical) reviewer platforms such as Couchsurfing or TripAdvisor (Dayter and Rüdiger 2014, Rosen et al. 2011, Vásquez 2011, 2014).

The special issue is wrapped up with two reviews of books that belong to the im/politeness research field: Daria Dayter reviews Mills' (2017) book English Politeness and Class, while Zsófia Demjen discusses Locher's (2017) book on Reflective Writing in Medical Contexts, which is written from an interpersonal pragmatics perspective. Vahid Parvaresh, finally, reports on the recent research trends observed during The 12th International Conference on (Im)Politeness, which was held in Cambridge, $\mathrm{UK}$, in 2019.

\section{Discussion and outlook}

The papers in this special issue reflect the enriching cross-fertilization of theories, methods and approaches which is typical of present-day im/politeness research. It is noteworthy that rather than focusing on politeness, several papers are on conflict and disagreement and thus reflect on politeness by studying how face-aggravation surfaces and is contrasted with expectations about politeness. They cover criticism in first encounter (Haugh \& Chang), discussions of the religious moral order and prayers that are face-aggravating (Al Zidjaly), and disagreement in a family about feminism (Fernández-Amaya). In the case of the practice of reviewing in Airbnb studied by HernándezLópez, overt face-aggravation is avoided but the omission of face-enhancing relational work is interpreted as negative. This finding was only possible by establishing the virtual community of practice norms rather than only counting on the linguistic surface structure to index face-maintenance. The two papers on reprimands and invitations in Russian reveal cultural indexicals of $\mathrm{im} /$ politeness in the speech acts involved (Bragina \& Sharonov, Vlasyan \& Kozhukhova). In Tzanne and Sifianou's contribution we learn about the ingroup and outgroup creation of impolite and polite identities. Rhee's paper demonstrates how norms established to index respect and hierarchies in address terms changes over time as these very forms become weaker in their expressive power. Terkourafi's contribution questions the classic understanding of the connection between indirectness and im/politeness and posits a hypothesis of increasing directness in connection with urbanization and globalization.

The papers have in common that they add insights about im/politeness discourses in different cultures. They use and combine different methods to uncover the norms based on which interactants arrive at im/politeness (and more generally relational) judgements. The data used reflects a wide scope from semi-authentic data (first encounters), discourse production tests, examples from large and custom-made corpora, online ethnography, and historical texts. These papers can be taken to reflect developments in im/politeness research. Rather than deploring that there is no single, unified $\mathrm{im} /$ politeness theory, we consider this variety enriching and wish to endorse the call for mixed methodologies and openness towards studying both culture specifics as well as universals in relational practices. While clearly much more needs to be done to understand the complexity of how different norms interact, how they give rise to im/politeness judgements and effects, and how we can uncover these processes of relational indexicalities, we are confident that the articles presented in this issue can be of use to the research community and become an impulse for further reflection, research and discoveries. 


\section{RU}

\section{1. Введение}

В 2014 году наш журнал посвятил специальный выпуск памяти Джеффри Лича, центральное место в котором было отведено изучению вежливости и невежливости. Он объединил ученых, чьи исследования дополнили публикации таких известных журналов в области прагматики, как Journal of Politeness Research, Pragmatics, Journal of Pragmatics и других, где исследователи не/вежливости находят своих читателей. Пять лет спустя мы снова обращаемся к данной теме. Когда мы объявили о подготовке данного выпуска и пригласили авторов участвовать в нем, мы рассматривали «глобальные контексты» в двух аспектах. С одной стороны, мы надеялись, что наши авторы представят исследования из области различных языков и контекстов, что расширит понимание не/вежливости, чаще всего исследуемой на материале английского и японского языков. Мы достигли этой цели благодаря тому, что наши авторы работают над самыми разными языками: английским, арабским, греческим, испанским, китайским, корейским и русским (перечислены в алфавитном порядке). С другой стороны, мы также хотели, чтобы в этом спецвыпуске нашли отражение теоретические и методологические вопросы изучения не/вежливости в глобальном контексте ${ }^{7}$ через обращение к культурным и языковым аспектам в различных лингвокультурах и развитие предыдущих сопоставительных дискурсивных исследований.

В данной статье мы сначала коротко остановимся на проблеме изучения не/вежливости. Затем дадим краткий обзор каждой отдельной статьи наших авторов, отметим новизну проведенных ими исследований, а также их теоретический и методологический вклад в изучение не/вежливости. В завершение обсудим результаты и наметим перспективы дальнейших исследований.

\section{2. Развитие теории не/вежливости, расширение методологии и сбора данных}

Начиная с раннего всплеска интереса к вежливости, вызванного работами Р. Лакофф (Lakoff 1973), П. Браун и С. Левинсона (Brown \& Levinson 1978, 1987), а также Дж. Лича (Leech 1983, см. также 2014), изучение вежливости является стабильно развивающимся направлением исследований в области социолингвистики, прагматики ${ }^{8}$ и дискурс-анализа, и ничто не указывает на снижение интереса к данной теме. Если в ранних работах по вежливости, где взгляд П. Грайса на формирование значения сочетался с анализом речевых актов, интерес проявлялся к прагматическому варьированию на уровне высказывания, то в последние десятилетия область изучения вежливости значительно расширилась. В предыдущих обзорах (Locher 2014, 2018) выделялось несколько таких областей, которые могут быть отнесены к двум блокам. Первый касается развития теоретической и методологической базы, второй — типа исследовательского материала и его охвата,

\footnotetext{
7 Уточним, что мы здесь не касаемся влияния глобализации на вежливость, о чем пишут Sifianou \& Garcés-Conejos Blitvich (2018) в специальном выпуске журнала Journal of Pragmatics.

8 Мы придерживаемся европейского определения прагматики, которое выходит за рамки предложения и включает изучение использования языка с социальной и культурной точек зрения (см. Locher \& Graham 2010: 1, Taavitsainen \& Jucker 2010 и др.).
} 
а также диапазона изучаемых языковых явлений. Глубокие и всесторонние обзоры по исследованию не/вежливости можно найти в книге Palgrave Handbook of Linguistic (Im)politeness (Culpeper et al. 2017). В данном кратком введении мы выделим лишь несколько актуальных вопросов.

В ранних исследованиях интерес проявлялся прежде всего к тому, как стратегии и тактики смягчения воздействия способствуют сохранению лица слушающего и говорящего (Здесь и далее под термином Э. Гоффмана «лицо» понимается социальный имидж человека). В них обычно рассматривались определенные речевые акты на уровне отдельного высказывания. Как следствие, смягчение воздействия стало почти синонимом вежливости, независимо от того, воспринимали ли сами участники свои действия как акты выражения вежливости или нет. На бытовом уровне, напротив, вежливость часто связывают с правилами, предписанными в книгах по этикету, которые включают как вербальные, так и более общие формы поведения. Таким образом, вежливость имеет мультимодальную природу и опирается на различные идеологии должного поведения. Этот мультимодальный взгляд на нормы вежливости разделяют многие ученые, включающие в свой анализ (как правило, качественный анализ дискурса и конверсационный анализ) выражение лица, жесты и др. Их интересует взаимодействие различных норм. Однако в исследованиях, которые проводятся на основе дискурсивных тестов (DCT, DPT) и корпусной лингвистики, на мультимодальность обращается меньше внимания.

Различие между эмическим (бытовым) и этическим (теоретическим, научным) пониманием не/вежливости привело к дискурсивному подходу к изучению данных явлений (см. Eelen 2001). Наиболее существенным вкладом в него стало указание на оценочный и контекстуальный характер таких понятий, как вежливость и невежливость, на важность эмоций в их оценке и утверждение о связи этих процессов с конструированием идентичности (например, Haugh et al. 2013, Linguistic Politeness Research Group 2011, Langlotz \& Locher 2017, Locher 2004, 2015, Locher $\&$ Watts 2005, 2008). В настоящее время общепринято сочетать эмический и этический подходы для учета их взаимосвязи ${ }^{9}$. Например, в анализе конкретных взаимодействий этические понятия «понижение лица» (т.е. понижение социального имиджа), «поддержание лица» (поддержание социального имиджа) и «улучшение лица» (повышение социального имиджа) могут быть связаны с такими эмическими оценками, как невежливый или грубый (см. Locher 2015: 8, Haugh \& Chang и Fernández-Amaya в этом выпуске).

В целом в течение последних десятилетий существенно расширяется материал исследований. Во-первых, ученые заинтересовались диахроническим аспектом изучения вежливости, ее историческими формами и их развитием (например, Culpeper \& Kádár 2010, Jucker \& Kopaczyk 2017, Paternoster \& Fitzmaurice 2019, Ратмайр 2009 и др.). В этих исследованиях показано изменение норм и то, как стратегии вежливости со временем развиваются и встраиваются в культурный контекст и идеологию поведения. Во-вторых, ученые также заинтересовались невежливостью и грубостью и перестали концентрировать свое внимание в первую

9 Garcés-Conejos Blitvich \& Sifianou (2019: 94) называют это третьей волной исследования вежливости, которая, как мы полагаем, сопутствовала второй волне, а не следовала за ней. 
очередь на смягчении угрозы лицу. Они расширили сферу своих исследований и включили в нее поведение, понижающее лицо (например, Bousfield 2008, Bousfield \& Locher 2008, Culpeper 2011, Жельвис 2001/1997, 2014; Ларина, Харлова 2014, Харлова 2015, специализированные конференции по невежливости и грубости, такие как LIAR, конференция «Вежливость и антивежливость в языке и коммуникации» [Шаронов 2018]). В-третьих, хотя по-прежнему существует серьезное направление, которое рассматривает отдельные речевые акты на уровне высказываний, многие исследователи работают с более длинными фрагментами речи и исследуют, как реляционное значение раскрывается в контексте в течение нескольких ходов (см. Garcés-Conejos Blitvich \& Sifianou 2019: 94). Наконец, материал, исследуемый в настоящее время, отличается разнообразием и включает межличностное общение, проходящее в естественных условиях, интернет-общение, письменные тексты различных стилей и жанров и др. Неудивительно, что с начала 2000-х годов изучение интернет-общения получило особый импульс, о чем свидетельствуют специальные выпуски журналов, монографии и многочисленные научные статьи (см. также обзор Парвареша в этом выпуске). Отметим при этом, что исследователи работают с материалом по своему выбору, используют комбинированные методы, дополняя, например, данные естественной коммуникации данными, полученными в ходе интервью или дискурс-тестов.

Расширение предметной области имеет важное значение для развития теории не/вежливости. Изменчивость и вариативность в выражении отношения к лицу, о которых свидетельствуют диахронические исследования, означает, что необходимо пересмотреть наше понимание того, что именно является универсальным в исследованиях вежливости. Если это не внешнее проявление вежливости, то, скорее всего, это способность людей (идеальной личности, согласно Brown \& Levinson 1987) осознавать свои собственные потребности и потребности адресата и использовать язык стратегически для достижения той или иной цели. Много усилий было вложено в изучение выявления культурных особенностей понимания, восприятия и выражения вежливости, результаты которых также показывают ее вариативность. Как продемонстрировали многочисленные кросс-культурные исследования, хотя вежливость по сути является универсальной категорией, ее конкретное выражение культурно специфично. Представление о том, что вежливо, а что нет, в разных культурах может различаться (см. Sifianou 1992, Watts 2003, Ратмайер 2003, Ларина 2003, 2004, 2009 и многие др.). Один и тот же акт (вербальный или невербальный), воспринимаемый как вежливый в одной культуре, может рассматриваться как неуместный, невежливый и даже грубый в другой (Larina 2015: 197, см. также Haugh \& Chang в этом номере) ${ }^{10}$. Это справедливо также и для субкультур в рамках одной этнической культуры (см., например, Брагина 2018).

${ }_{10}$ Как справедливо утверждает Уоттс (Watts 2003: 14), лексемы polite и politeness и соответствующие им термины в других языках могут различаться по значению и связанным с ними коннотациям, что также было показано в исследованиях М. Сифиану (Sifianou 1992), Лариной (2003, 2004, 2009), Ратмайр (2003) и др. В зависимости от исследовательского вопроса, этот вывод имеет то или иное методологическое применение (см., например, исследование М. Лохэр [Locher 2012], в котором выявляются различия между невежливостью и грубостью на основе коннотаций английских лексем при изучении других языков) [Locher 2012: 50]). 
В результате исследователи прилагают большие усилия для изучения того, как культура в целом, а также нормы, разработанные в различных контекстах и на разных уровнях (например, личностные, ситуативные, текстовые, см. [Culpeper 2008: 30]), информируют о вежливости и формируют ее. Знание того, что влияет на конкретное высказывание, означает, что собеседники знают нормы той или иной лингвокультуры на разных ее уровнях и могут использовать эти знания для сохранения, понижения или повышения своего лица или лица адресата. Они делают это в конкретной ситуации, то есть используют индексальную силу своего языкового выбора в конкретное время и в конкретном контексте. При этом существует сложная взаимосвязь между идеологиями, нормами данного сообщества, совершаемыми коммуникантами действиями и выбором языковых средств) ${ }^{11}$.

Кроме того, расширение области исследования способствует также изучению прагматической вариативности в выражении различных речевых актов и выявлению их значения в более длинных фрагментах речи в различных контекстах. Это связано с тем, что данная область является предметом внимания не только исследователей, занимающихся не/вежливостью (подробно см. Locher 2015). Сообщество исследователей не/вежливости обращается к другим областям, и в настоящее время существует целый ряд теорий и подходов, которые могут взаимно обогащать друг друга. Среди них - теория создания лица ('face-constituting theory') (Arundale 2010, 2013 и др.), управление взаимоотношениями ('rapport management') (Spencer-Oatey 2005, 2009), работа по улучшению отношений, или реляционная работа ('relational work') в межличностной прагматике (Locher \& Watts 2005, 2008; Locher \& Graham 2010), исследования жанра и дискурса (Garcés-Conejos Blitvich 2010, Garcés-Conejos Blitvich \& Sifianou 2019), влияние вежливости на стили коммуникации (Ларина 2003, 2009, House 2006, Larina 2015), исследования по построению идентичности (например, Bucholtz \& Hall 2005, 2008; Hall \& Bucholtz 2013). Последнее направление представляется особенно перспективным, поскольку оценка вежливости всегда оказывает влияние на конструирование идентичности (см. Locher 2008, Garcés-Conejos Blitvich 2009, Garcés-Conejos Blitvich \& Sifianou 2017, Larina et al. 2017a, b), что в свою очередь определяет стиль коммуникации (см. Garcés-Conejos Blitvich 2009, Garcés-Conejos Blitvich \& Sifianou 2017, Locher 2008, Земская 1997, Ларина 2003, 2009).

В обзоре Международного симпозиума по не/вежливости 2019 г. эти общие тенденции в изучении рассматриваемого явления также нашли отражение. Участники симпозиума, которые собрались, чтобы представить результаты своих исследований в области вежливости и невежливости, продемонстрировали взаимообогащающее разнообразие методологий и теорий. Они показали, что набирают силу исследования вежливости в диахроническом аспекте; по-прежнему остается актуальным исследование онлайн-коммуникации; изучение речевой

${ }^{11}$ Garcés-Conejos Blitvich \& Sifianou (2019: 97) называют это сложное взаимодействие микро (стиль), мезо (жанр) и макро (дискурс) и основывают свою аргументацию на взглядах Фэйрклафа (Fairclough 2003). 
агрессии помогает выявить индексальность (маркированность) высказываний; в дополнение к личным, культурным, ситуативным и текстовым нормам (Culpeper 2008: 30) приобретает все большее значение концептуализация этики поведения; продолжаются исследования, учитывающие оценочный характер не/вежливости (Locher 2004); разрабатываются понятия невежливости и конфликта; продолжают изучаться отдельные речевые акты как в рамках одной культуры, так и в сопоставлении с различными лингвокультурами. В ходе симпозиума неоднократно обсуждались вопросы, касающиеся сбора материала. В целом, было показано, что данная исследовательская область имеет широкие перспективы. Ниже мы кратко представим наших авторов и их статьи, которые продолжат обсуждение вышеперечисленных вопросов.

\section{3. Авторы и статьи выпуска}

В данном выпуске представлены девять оригинальных исследований. Авторы первой статьи Майкл Хо и Вей-Лин Мелоди Чанг исследуют речевой акт «критика» с межъязыковой и межкультурной точек зрения. Выдвигая на первый план методологические проблемы, они создают основу для последующих работ, касающихся подходов к вежливости и невежливости в глобальном контексте. Далее идет теоретическая статья Марины Теркурафи, в которой представлен мета-анализ меняющейся роли косвенности в исследованиях не/вежливости. Следующие три статьи посвящены различным языкам, исследование которых осуществляется на разных методологических принципах: Сингха Ри применяет диахронический метод к анализу корейского языка; исследователи русского языка Н.Г. Брагина и И.А. Шаронов используют корпусную лингвистику и дискурс-анализ, а Г.Р. Власян и И.В. Кожухова работают с дискурсивными тестами. Таким образом, статьи показывают, что мы можем получать данные о различных языках, контекстах и культурах с помощью широкого спектра методологий, о чем свидетельствуют и остальные статьи. Последние посвящены исследованию естественной речевой коммуникации, осуществляемой с применением современных компьютерных технологий. В последние два десятилетия исследование вежливости в онлайн-контексте интенсивно развивается (см., например, Graham \& Hardaker 2017, Locher 2006, Locher et al. 2015). Статьи нашего спецвыпуска продолжают обсуждение методологических и теоретических подходов и дают представление о различных языках и культурах в онлайн-общении. Отдельно остановимся на каждой из статей.

Открывает выпуск статья Майкла Хо и Вей-Лин Мелоди Чанг, которая посвящена анализу речевого акта «критика» в ситуации первой встречи собеседников. Материалом для исследования послужили диады на английском языке, записанные в Австралии, и диады на китайском языке (мандарин), записанные на Тайване. В центре анализа находятся речевые действия, содержащие критику собеседника. В то время как многие исследования сосредоточены на сравнении языковой реализации речевых актов, авторы утверждают, что комплексный последовательный и индексальный анализ помогает лучше понять не только межъязыковые различия, но и различный статус содержания того или иного речевого акта и его индексальное значение в разных культурах. Авторы обращаются к мето- 
дологическим проблемам анализа материала, когда исследователи являются или не являются частью изучаемого сообщества, последствиям влияния этого факта на анализ и теоретические выводы, касающиеся не/вежливости. Они обращают внимание на то, что слово «критика» само по себе может иметь различные коннотации в разных культурах и что недостаточно ограничиваться сравнением одной лишь языковой формы, поскольку у собеседников могут быть разные интерпретации данного речевого акта. Это важное заключение находит дальнейшее развитие и в статье Фернандес-Амайя (в этом выпуске), анализирующей речевой акт «несогласие» (см. ниже).

Марина Теркурафи обращает внимание на роль косвенности в исследованиях не/вежливости в свете процессов урбанизации и глобализации. Хотя использование косвенности традиционно связывается с сохранением лица и рассматривается как универсально безопасная стратегия (Brown \& Levinson 1987), она предлагает альтернативную точку зрения. Сочетая теорию вежливости с так называемой теорией сетей ('network theory') (Milroy 1987), Теркурафи объясняет, что для интерпретации косвенности необходимы внутригрупповые знания, и поэтому то, что она называет случайной косвенностью ('accidental indirectness'), свойственно только для данной группы. Как следствие, косвенность может стать и нежелательной стратегией. Представляя мета-анализ трех исследований в различных лингвистических и культурных контекстах, которые предлагают диахроническую перспективу использования косвенности (Morgan [1991] о косвенности в сообществе афро-американских женщин; He et al. [2012] о комплиментах в китайском языке; Jucker [2012] о развитии английской вежливости), Теркурафи выдвигает гипотезу о том, что общее ослабление межличностных отношений может быть причиной потенциального увеличения прямых, а не косвенных языковых стратегий. Дальнейшее изучение этой гипотезы представляет интерес для исследований вежливости и невежливости, поскольку ставит под сомнение одно из основных теоретических положений.

Сингха Ри пишет о корейском языке, где вежливость грамматикализована, то есть маркировка вежливости получает не только прагматическое, но и грамматическое оформление. В корейском языке отношение говорящего к адресату выражено обязательной частицей в конце предложения (Rhee \& Koo 2017: 101), кроме того, существует разнообразная и сложная система местоимений и терминов обращения, которая включает как термины родства, так и термины, выражающие иерархию и старшинство. Опираясь на идеи «эмерджентной грамматики 'emergent grammar' (Hopper 1987), Ри исследует развитие местоимений первого и второго лица и их связь с терминами обращения и референции в диахронической перспективе. Он показывает, как с помощью языковых указателей (местоимений и маркеров почтения/уничижения) выражается необходимая для корейской вежливости более высокая позиция адресата и более низкая позиция адресанта. Данная система местоимений и терминов обращений весьма динамична, она постоянно развивается, для того чтобы удовлетворить коммуникативные потребности участников общения. Это развитие обусловлено сложностью выбора адекватных маркеров вежливости, поскольку выбор неправильного уровня вежливости или неис- 
пользование должного термина обращения может привести к нежелательному прагматическому результату. С. Ри утверждает, что точно так же, как табуированные слова со временем теряют свою силу, местоимения в результате частого употребления теряют свою способность индексировать определенный уровень вежливости. Как следствие, термины почтения [+Honorific] постоянно обновляются, чтобы повысить снижающийся эффект почитания, а термины обозначения первого лица [+Humiliative] обновляются для усиления эффекта самоуничижения. Данное исследование показывает, что обращение к диахронической перспективе обогащает теорию вежливости новыми данными. Тот факт, что местоименные маркеры вежливости изменяются во времени, свидетельствует о динамичном характере языковых реализаций актов позиционирования, которые необходимы для выражения вежливости ${ }^{12}$. При этом сама необходимость выражать эти различия через позиционирование представляется стабильной.

Н.Г. Брагина и И.А. Шаронов рассматривают повседневное неформальное общение в русской культуре. В статье представлен анализ более 200 диалогов, взятых из Национального корпуса русского языка, в которых содержится угроза лицу собеседника в виде выговора за неуместный характер предыдущего высказывания. Авторы называют такой выговор «педагогической агрессией» в связи с его корректирующим характером и негативным отношением. Из-за этих особенностей они определяют подобные выговоры как невежливые и противопоставляют их ответам, направленным на нейтрализацию ранее воспринятого неуместного высказывания (эмпатийной стратегии). В ходе своего исследования авторы выделяют три тактики «агрессивно-педагогической» стратегии, предполагающие использование: (1) ответных псевдовопросов (риторических вопросов и вопросов, обращенных к презумпциям собеседника, его исходным предположениям); (2) передразнивающих цитаций; (3) рифмованных псевдоответов. В центре внимания данной статьи - третий тип высказываний. Авторы показывают, что рассматриваемая стратегия оценивается носителями русского языка как невежливая, но возможная, поскольку, как они отмечают, существует негласная презумпция, согласно которой в неформальном общении по отношению к совершившему коммуникативную ошибку собеседнику позволительно агрессивно-воспитательное речевое поведение. Для реализации этой стратегии в русском языке существует набор шаблонных речевых формул. В статье показано, что в ситуации близких отношений использование рифмованных псевдо-ответов может носить шутливый характер и не приводить к конфликту, однако в дальнейшей коммуникации говорящий все равно должен объяснить и компенсировать свой выпад против собеседника. В конфликтном диалоге стереотипные псевдо-ответные фразы используются, чтобы разорвать контакт с собеседником или переключиться на другой

12 Мы не говорим здесь о том, что «все идет» и что все постоянно изобретается заново с нуля (как это неверно истолковано некоторыми критиками дискурсивного подхода). Маркеры не/вежливости опираются на принятые в обществе нормы, которые, однако, со временем могут меняться, что убедительно продемонстрировано в статье Ри (более подробно об этом см. Locher 2012: 52). 
режим коммуникации. Авторы исследования убедительно показывают, что стратегия педагогической агрессии заслуживает особого внимания, поскольку она контрастирует с эмпатийной стратегией. Этот вывод подчеркивает, что в реальной ситуации непосредственного общения маркированность вежливости и невежливости определяется через противопоставление. Данное теоретическое положение связано с дискурсивным подходом к изучению не/вежливости, который был предложен и разработан рядом ученых (например, Haugh et al. 2013, Linguistic Politeness Research Group 2011, Locher \& Watts 2005, 2008, 2015) и развивается авторами данного спецвыпуска (см. ниже).

Г.Р. Власян и И.В. Кожухова исследуют вежливость в русском языке на материале данных дискурсивного теста, в котором приняли участие респонденты трех возрастных групп: школьники, студенты университета и взрослые. Их задача состояла в том, чтобы сформулировать приглашение в ситуациях, которые различались в зависимости от возраста и социального статуса участников, т.е. с учетом как симметричных (неформальный контекст), так и асимметричных (формальный контекст) отношений. Респонденты должны были пригласить (а) друга/коллегу и (б) учителя/начальника на мероприятие или день рождения. Авторы хотели выявить различия в выражении приглашения в формальном и неформальном контекстах и уточнить характеристики речевого акта «приглашение» в понимании русских. Результаты проведенного исследования показали, что, несмотря на существующие различия в стратегиях и языковых средствах реализации данного речевого акта в формальном и неформальном контекстах, в целом предпочтение отдается прямым приглашениям, что соответствует русскому стилю коммуникации (см. Ларина 2003, 2008, 2009, 2015). В симметричных контекстах в группах «школьники» и «студенты» наиболее типичной формой приглашения является императив (Приходи(те) ко мне в субботу на день рождения), в группе «взрослые», а также во всех трех группах в формальном (асимметричном) контексте - перформатив (Я приглашаю тебя (Вас) на день рождения). Косвенные приглашения также существуют, но они встречаются реже и не являются преобладающими ни в одной из исследуемых групп. Этот вывод согласуется с идеей о том, что в русском языке предоставление выбора в приглашении может быть истолковано не как проявление уважения к желаниям слушателя, а как свидетельство неискренности говорящего (Leech \& Larina 2014: 15) и может восприниматься негативно. Вместо хеджирования респонденты всех трех групп, напротив, использовали различные интенсификаторы воздействия как в неформальном, так и формальном контексте (Tы обязательно должен прийти / твое присутствие обязательно / отказ не принимается / Я (мы) очень хочу (хотим) тебя (Вас) видеть / Я (мы) буду (будем) очень рад(paдbl) тебя (Bac) видеть), делая таким образом акцент на интересах приглашающего, а не приглашаемого. Результаты исследования дают новые данные о речевом акте «приглашение» и свидетельствуют о том, что в русской культуре приглашение не является угрожающим лицу актом, во всяком случае в той степени, как это имеет место в англосаксонских культурах. Они подтверждают идею о том, что в русской культуре с ее по-прежнему коллективистской 
направленностью (Larina et al. 2017a, b), прямолинейность не всегда нарушает принципы вежливости и во многих речевых актах и контекстах она ожидается и воспринимается позитивно. Полученные данные также показывают, что культурные различия в коммуникации не случайны, а системны и регулярное использование типичных стратегий приводит к формированию коммуникативных особенностей, совокупность которых формирует коммуникативный этностиль (Larina 2015: 197).

Как упоминалось в предыдущем разделе, исследовательское сообщество давно признало, что оценка вежливости связана с нормами различных типов. Дж. Калпепер (Culpeper 2008: 30) говорит о личных, культурных, ситуативных и текстовых нормах, которые выстраивают взаимодействие. Д. Кадар и М. Хо (Kádár \& Haugh 2013: 95), в свою очередь, упоминают «локализованные нормы» ('localised norms') — нормы сообщества/организации или другие групповые нормы и социальные/культурные нормы. Выделить эти нормы - одна из задач исследователей вежливости. Ангелики Цанне и Мария Сифиану ставят перед собой эту задачу и задаются вопросом, где и как исследователи могут получить информацию о том, как представители того или иного сообщества понимают вежливость и невежливость. В своем исследовании они, таким образом, ищут ответ, касающийся того, как выявить нормы, то есть как узнать, что воспринимается как не/вежливость в определенном контексте. Вместо того, чтобы изучать взаимодействие между участниками коммуникации или обращаться к книгам по этикету (что, безусловно, является ценным источником), они утверждают, что ученые могут также получить много информации, обратившись к тому, как вопросы о вежливости/невежливости освещаются в СМИ. Именно поэтому в фокусе их интереса мета-дискуссии в публичном пространстве, которые указывают на социальное, а не индивидуальное понимание невежливости. Материалом исследования послужили две онлайн-статьи о невежливости в Греции, написанные одним и тем же журналистом, которые были распространены в средствах массовой информации и вызвали отклик читателей. Анализируя статьи и комментарии к ним с помощью концепций дискурсивного конструирования идентичности и идей Ван Дейка (van Dijk 1998, 2006a, b) об идеологической позитивной презентации себя и негативной презентации другого, авторы показывают, что невежливость воспринимается не только как лингвистический феномен, но она охватывает все виды поведения в публичном и частном пространстве и, что особенно важно, «вежливый» и «невежливый гражданин» совместно конструируются журналистом и авторами постов как бинарные противоположности.

Хотя такие взгляды в определенной степени являются стереотипными, они демонстрируют повторяющиеся и распространенные представления о нормах вежливости на бытовом уровне. Авторы показывают, что «своя» группа вежливых граждан конструируется как превосходящая по сравнению с «чужой» группой невежливых граждан и они различаются по таким признакам, как власть, образование, культура и интеллект. Таким образом, в данном исследовании показано, как анализ мета-дискуссий в Интернете может способствовать углублению нашего 
понимания о концептуализации не/вежливости носителями того или иного сообщества. Отметим, что хотя процесс противопоставления убедителен, параметры контрастирования могут легко сдвигаться, что показано в (Locher \& Luginbühl 2019), где также были проанализированы статьи в газетах и комментарии читателей. В последнем случае инициирующие тексты противопоставляли немецкую вежливость швейцарским (немецким) нормам вежливости. Интересно отметить, что, как было установлено, швейцарцы, говорящие на немецких диалектах, выстроили свое единое швейцарское понимание вежливости, противопоставив ее немецкой, однако, когда речь шла только о Швейцарии, они отметили разницу в диалектных нормах. Это связано с тем, что в Швейцарии существует множество диалектов, но, по-видимому, при сравнении с внешней группой ситуация упрощается.

Статья Наджмы Аль Зиджали дает еще одну перспективу исследования вежливости и невежливости. Ее статья, озаглавленная «,Божественная невежливость“: как арабы обсуждают исламский моральный порядок в Твиттере», является результатом долгих этнографических онлайн-наблюдений над построением арабской идентичности в социальных сетях. В многочисленных публикациях Аль Зиджали продемонстрировала, как религиозный нравственный порядок влияет на построение арабской идентичности и понимание себя (Al Zidjaly 2014, 2017, 2019 и др.). Для этой статьи автором был выбран один конкретный твит, который вызвал много комментариев и оставался в центре внимания СМИ в течение значительного времени. В нем обсуждалась хорошо известная молитва, в которой немусульмане, в отличие от мусульман, не упоминались в просьбах к всевышнему о здоровье. Автор твита подвергает сомнению моральную сторону этого опущения и приглашает к дискуссии. Поскольку ставить под сомнение Коран и хадисы (высказывания пророка, задокументированные в авторитетных книгах Sahih AlBukhari и Sahih Al-Muslim) не разрешено, обсуждение является спорным изначально. Однако, как выясняется в ходе дискуссии, слова молитвы взяты не из Корана и не из хадисов, что сделало возможным высказывать различные мнения и участвовать в их обсуждении. То, что Аль Зиджали называет агрессивной «божественной невежливостью», является повторяющейся стратегией, комментаторы обращаются к религиозным авторитетным текстам, которые агрессивны по отношению к другим, и цитируют их, чтобы узаконить потерю лица тех, кто исключен из молитвы о здоровье. По мнению автора статьи, эти онлайн-дискуссии являются свидетельством сдвига в исламском моральном порядке, обсуждение которого становится все более возможным в онлайн-контекстах. Поскольку работы по не/вежливости в арабском языке немногочисленны и эта тема только начинает интересовать арабских исследователей (например, Badarneh 2019, Farhat 2013, Labben 2018), данная статья имеет особое значение. В ней подчеркивается сложность различных типов норм, которые переплетаются при рассмотрении не/вежливости, и освещается религиозный нравственный порядок, о котором светские западные ученые могут иметь неполное представление.

Статья Люсии Фернандес-Амайя представляет собой исследование конкретной ситуации общения членов испанской семьи, которое проходило в WhatsApp в течение 14 часов. В данном фрагменте дискурса объемом более 9900 слов данная 
группа обсуждает демонстрацию, проведенную по случаю Международного женского дня. Как оказалось, члены семьи придерживаются диаметрально противоположных взглядов на феминизм и выражают их в чате в WhatsApp. Это приводит к длительным спорам, участники которых выражают и отстаивают собственные точки зрения и реагируют на мнения других. Таким образом, в фокусе исследования - выражение несогласия, поддержание мнений других и расхождение с ними. В качественном анализе 427 случаев выражения несогласия Фернандес-Амайя сначала создает типологию несогласий, затем систематизирует установленные стратегии (чаще всего это выражение противоположного мнения и объяснение эмоциональных и личных причин) и анализирует их распределение между членами семьи, что дает возможность показать, как они различаются по своим предпочтениям. На втором этапе исследования участникам дискуссии в WhatsApp была отправлена электронная анкета и соответствующие фрагменты, чтобы установить, оценивают ли они прямое несогласие и высказывание часто диаметрально противоположных позиций как проявление невежливости. Результаты анализа показали, что члены семьи не считают подобные высказывания невежливыми и представляющими серьезную угрозу их лицу, напротив, их тесная связь и семейные узы позволили им выразить себя без опасения испортить свои отношения, а некоторые участники дискуссии даже оценили возникшие разногласия как позитивные. Таким образом, представленные результаты и выводы дополнили новыми данными исследования по выражению несогласия и реляционной работе, которые показали, что в процессе коммуникации несогласие часто ожидаемо и оно не обязательно имеет отрицательную маркированность (см. подробно, например, Angouri \& Locher 2012). Полученные выводы подтверждают мнение Хо и Чанг, анализирующих выражение критики (в этом выпуске), о том, что для оценки того или иного акта как вежливого или невежливого, его индексальная оценка и реализация должны быть проанализированы в контексте.

Мария де ла О Эрнандес-Лопес исследует отзывы потребителей на англоязычной онлайн-площадке Airbnb. Подобно Д. Дайтер и С. Рюдигер (Dayter \& Rüdiger 2014), которые исследовали комментарии клиентов на сайте гостевой сети Couchsurfing, Эрнандес-Лопес показывает их действия в таком деликатном акте, как отзыв, где на карту поставлено публичное лицо как принимающей стороны, так и гостей сайта. Проанализировав 120 отзывов, автор выявляет три разные эмоциональные оценки: восхищение/удовлетворение, амбивалентность/нейтральность и неудовлетворение/разочарование, которые затем обсуждаются в связи с выявлением преобладающих норм (см. Locher \& Watts 2005, 2008). Результаты указывают на явное предпочтение авторов отзывов быть вежливыми и избегать откровенных грубостей или оскорблений. Однако из-за этой нормы позитивности умалчивание также становится информативным, так как предполагается, что то, о чем не говорится, оценивается неудовлетворительно. Сообщения, приближающиеся к отрицательному полюсу шкалы, характеризуются деперсонализацией, формальным стилем и дистанцированием от хозяина отеля, тогда как сообщения с положительной оценкой содержат позитивную экспрессивную лексику. Автор установила соотношение между моделями выражения отношения и содержанием отзывов, 
а затем сравнила свои результаты с аналогичными (но не идентичными) платформами, такими как Couchsurfing или TripAdvisor (Dayter \& Rüdiger 2014, Rosen et al. 2011, Vásquez 2011, 2014). С точки зрения методологии статья дополняет наши представления о том, как могут быть изучены нормы конкретного сообщества.

Специальный выпуск завершают две рецензии на книги, относящиеся к области исследования вежливости и невежливости: Дарья Дайтер рецензирует книгу Сары Миллс English Politeness and Class (Английская вежливость и класс) (2017), а Жофиа Дэмен - книгу Мириам Лохэр Reflective Writing in Medical Contexts (Рефлексивное письмо в медицинских контекстах) (2017), которая написана с позиций межличностной прагматики. Вахид Парвареш дает обзор 12-й Международной конференции по вежливости и невежливости, состоявшейся в Кембридже, Великобритания, в июле 2019 г., в котором очерчивает основные направления обсуждавшихся на конференции исследований.

\section{4. Обсуждение и перспективы}

Статьи нашего специального выпуска отражают взаимообогащение теорий, методов и подходов, что характерно для современных исследований в области не/вежливости. Следует отметить, что вместо того, чтобы фокусироваться на вежливости, некоторые статьи посвящены конфликтам и разногласиям. Таким образом, через изучение вежливости рассматривается, как наносится урон лицу и как это контрастирует с ожиданиями вежливости. Среди тем статей - критика при первом знакомстве (Haugh \& Chang), обсуждение религиозного нравственного порядка и молитв, которые наносят урон лицу (Al Zidjaly), разногласия в семье по поводу феминизма (Fernández-Amaya). В исследовании, посвященном анализу отзывов на платформе Airbnb (Hernández-López), показано, что авторы отзывов избегают явного нанесения урона лицу, но отсутствие действий по улучшению лица воспринимается как негативная оценка. Получить данные результаты стало возможным не только через оценку поверхностных языковых структур, указывающих на сохранение лица, но и благодаря установлению практических норм виртуального сообщества. В двух статьях на русском языке о замечаниях и приглашениях раскрываются культурные знаки не/вежливости в рассматриваемых речевых актах (Брагина и Шаронов, Власян и Кожухова). Благодаря статье Цанне и Сифиану мы узнаем о внутригрупповом и внегрупповом представлении о невежливой и вежливой идентичности. Статья Ри демонстрирует, как нормы, установленные для фиксации уважения и иерархии в терминах обращения, со временем меняются, поскольку теряют свою выразительную силу. М. Теркурафи ставит под сомнение классическое понимание связи между косвенностью и вежливостью и выдвигает гипотезу о появлении тенденции к развитию прямолинейности в связи с урбанизацией и глобализацией.

Общим в статьях выпуска является то, что они вносят вклад в развитие представлений о проявлении не/вежливости в разных типах дискурса в различных культурах. Авторы используют и комбинируют различные методы, чтобы раскрыть нормы, на основании которых участники общения делают вывод о вежливости и невежливости. Используемый для анализа материал свидетельствует о его 
широком диапазоне: это полуаутентичные данные, данные дискурсивных тестов, онлайн коммуникация, корпусные данные, исторические тексты и др. Эти статьи дают возможность проследить развитие исследований в области не/вежливости. Вместо того, чтобы сожалеть об отсутствии единой, всеохватывающей теории не/вежливости, мы считаем наблюдаемое на данный момент разнообразие теоретических и методологических подходов обогащающим и хотим поддержать призыв к комплексности подходов, взаимообогащению методологий, к открытости в изучении как культурноспецифичных, так и универсальных реляционных практик.

Очевидно, что для понимания сложностей взаимодействия различных норм, того, как они влияют на оценку высказываний и передаваемых ими отношений, на выражение вежливости и невежливости в различных социальных и культурных контекстах, многое еще предстоит сделать. Тем не менее мы надеемся, что представленные в нашем выпуске статьи будут полезными для научного сообщества и могут стать импульсом для дальнейших размышлений, научных поисков и открытий.

(C) Miriam A. Locher and Tatiana V. Larina / Мириам А. Лохэр, Т.В. Ларина, 2019 cc) creative https://creativecommons.org/licenses/by/4.0/

\section{REFERENCES / СПИСОК ЛИТЕРАТУРЫ}

Al Zidjaly, Najma (2014). WhatsApp Omani teachers? Social media and the question of social change. Multimodal Communication, 3 (1), 107-130.

Al Zidjaly, Najma (2017). Mental health and religion on Islamweb.net. Linguistik Online. http://dx.doi.org/10.13092/lo.87.4178.

Al Zidjaly, Najma (2019). Digital activism as nexus analysis: A sociolinguistic example from Arabic Twitter. Tilburg Papers in Culture Studies, paper 221.

Angouri, Jo \& Miriam A. Locher (2012). Theorising disagreement. Journal of Pragmatics, 44 (12), $1549-1553$.

Arundale, Robert B. (2010). Relating. In Miriam A. Locher \& Sage Lambert Graham (eds.). Interpersonal Pragmatics, 137-167. Berlin: Mouton.

Arundale, Robert B. (2013). Face as a research focus in interpersonal pragmatics: Relational and emic perspectives. Journal of Pragmatics, 58, 108 - 120. doi: 10.1016/j.pragma.2013.05.013.

Badarneh, Muhammad A. (2019). 'Like a donkey carrying books': Intertextuality and impoliteness in Arabic online reader responses. Journal of Language Aggression and Conflict. https://doi.org/10.1075/jlac.00027.bad.

Bousfield, Derek (2008). Impoliteness in interaction. Amsterdam: John Benjamins Publishing Company.

Bousfield, Derek \& Miriam A. Locher (eds.). (2008). Impoliteness in Language. Studies on its Interplay with Power in Theory and Practice. Berlin: Mouton de Gruyter.

Bragina, Natalya G. (2018). Politeness as impoliteness: At the junction of different cultural norms and rules. In I.A. Sharonov (ed.) Politeness and impoliteness in language and communication, 38-44. Moscow: ROSPEN (In Russ.) 
Brown, Penelope \& Stephen C. Levinson (1978). Universals in Language Usage: Politeness Phenomena. In Esther N. Goody (ed.) Questions and Politeness, 56-289. Cambridge: Cambridge University Press.

Brown, Penelope \& Stephen C. Levinson (1987). Politeness. Some Universals in Language Usage. Cambridge: Cambridge University Press.

Bucholtz, Mary \& Kira Hall (2005). Identity and interaction: A sociocultural linguistic approach. Discourse Studies, 7 (4-5), 585-614.

Bucholtz, Mary \& Kira Hall (2008). Finding identity: Theory and data. Multilingua, 27 (1-2), $151-163$.

Culpeper, Jonathan (2008). Reflections on impoliteness, relation work and power. In Derek Bousfield \& Miriam A. Locher (eds.), Impoliteness in Language. Studies on its Interplay with Power in Theory and Practice, 17-44. Berlin: Mouton de Gruyter.

Culpeper, Jonathan (2011). Impoliteness. Using Language to Cause Offence. Cambridge: Cambridge University Press.

Culpeper, Jonathan \& Dániel Kádár (eds.). (2010). Historical (im)politeness (Vol. 65). Bern: Peter Lang.

Culpeper, Jonathan, Michael Haugh \& Dániel Z. Kádár (2017). Palgrave Handbook of Linguistic (Im)Politeness. London: Palgrave.

Dayter, Daria \& Sofia Rüdiger (2014). Speak your mind, but watch your mouth: Complaints in CouchSurfing references. In Kristina Bedijs, Gudrun Held \& Christiane Maaß (eds.), Face Work and Social Media, 193-212. Münster: Lit-Verlag.

Eelen, Gino (2001). A Critique of Politeness Theories. Manchester: St. Jerome Publishing.

Fairclough, Norman (2003). Analysing Discourse: Textual Analysis for Social Research. Routledge, London.

Farhat, Emdelellah (2013). Gender, power, politeness and women in the Arab society. Journal of English Language \& Translation Studies, 1 (1), 50-60.

Garcés-Conejos Blitvich, Pilar (2009). Impoliteness and identity in the American news media: The 'Culture Wars'. Journal of Politeness Research, 5, 273-303.

Garcés-Conejos Blitvich, Pilar (2010). A genre approach to the study of im-politeness. International Review of Pragmatics, 2, 46-94.

Garcés-Conejos Blitvich, Pilar (2018). Globalization, transnational identities, and conflict talk: The superdiversity and complexity of the Latino identity. Journal of Pragmatics, 134, 120-133. doi.org/10.1016/j.pragma.2018.02.001.

Garcés-Conejos Blitvich, Pilar \& Maria Sifianou (2017). (Im)politeness and identity. In Jonathan Culpeper, Michael Haugh, \& Dániel Z. Kádár (eds.), Palgrave Handbook of Linguistic (Im)Politeness, 227-256. London: Palgrave.

Garcés-Conejos Blitvich, Pilar \& Maria Sifianou (2019). Im/politeness and discursive pragmatics. Journal of Pragmatics, 145, 91-101. doi: 10.1016/j.pragma.2019.03.015.

Graham, Sage L. \& Claire Hardaker (2017). (Im)politeness in digital communication. In Jonathan Culpeper, Michael Haugh and Dániel Z. Kádár (eds.), Palgrave Handbook of Linguistic (Im)Politeness, 785-814. London: Palgrave.

Hall, Kira \& Mary Bucholtz (2013). Epilogue: Facing identity. Journal of Politeness Research, 9 (1), 123-132. doi: 10.1515/pr-2013-0006.

Haugh, Michael, Dániel Kádár \& Sara Mills (2013). Interpersonal pragmatics: Issues and debates. Journal of Pragmatics, 58, 1-11. doi: 10.1016/j.pragma.2013.09.009. 
He, Yun. (2012). Different generations, different face? A discursive approach to naturally occurring compliment responses in Chinese. Journal of Politeness Research, 8, 29-51.

Hopper, Paul J. (1987). Emergent Grammar. Berkeley Linguistic Society, 13, 139-157.

House, Juliane (2006). Communicative styles in English and German. European Journal of English Studies, 10(3), 249-267.

Jucker, Andreas H. (2012). Positive and negative face as descriptive categories in the history of English. In: Michael Bax \& Daniel Z. Kádár (eds.) Understanding Historical (Im)Politeness: Relational Linguistic Practice Over Time and Across Cultures, 175-194. Amsterdam: John Benjamins.

Jucker, Andreas H. \& Joanna Kopaczyk (2017). Historical (im)politeness. In Jonathan Culpeper, Michael Haugh, \& Dániel Z. Kádár (eds.). Palgrave Handbook of Linguistic (Im)Politeness, 433-459. London: Palgrave.

Kádár, Dániel \& Michael Haugh (2013). Understanding Politeness. Cambridge: Cambridge University Press.

Kharlova, Margarita (2014). The conceptualization of impoliteness in Russian and English. Russian Journal of Linguistics, 4, 119-131.

Kharlova, Margarita (2015). Emotions in impolite and rude communication. Russian Journal of Linguistics, 3, 84-98.

Labben, Afef (2018). Face and identity in interaction: A focus on Tunisian Arabic. Journal of Pragmatics, 128, 67-81.

Lakoff, Robin Tolmach (1973). The logic of politeness, or minding your p's and q's. Chicago Linguistics Society, 9, 292-305.

Langlotz, Andreas \& Miriam A. Locher (2017). (Im)politeness and emotion. In Jonathan Culpeper, Michael Haugh \& Dániel Z. Kádár (eds.), Palgrave Handbook of Linguistic (Im)Politeness, 287-322. London: Palgrave.

Larina, Tatiana (2003). The category of politeness in the English and Russian communicative cultures. Moscow: RUDN University Publ. (In Russ.)

Larina, Tatiana (2004). The concept of politeness in the communicative consciousness in the Russians and the English. In L. Szypielevicz (ed.) Człoviek Świadomość Komunikacja Internet. Warszawa, 284-293 (In Russ.)

Larina, Tatiana (2008). Directness, Imposition and Politeness in English and Russian. Cambridge ESOL: Research Notes, 33, 33-38.

Larina, Tatiana (2009). Politeness and Communicative Styles: Comparative analyses of English and Russian lingua-cultural traditions. Moscow: Yazyki slavyanskikh kul'tur (In Russ.).

Larina, Tatiana (2013). The English and the Russians: Language, Culture and Communication Moscow: Yazyki slavyanskikh kul'tur (In Russ.).

Larina, Tatiana (2015). Culture-Specific Communicative Styles as a Framework for Interpreting Linguistic and Cultural Idiosyncrasies. International Review of Pragmatics, 7, 195-215.

Larina, Tatiana \& Margarita Kharlova (2015). Impoliteness and rudeness in interpersonal communication of Americans. Bulletin of the Novosibirsk State University. Series Linguistics and Intercultural Communication,13, (3), 34-42 (In Russ.)

Larina, Tatiana, Vladimir Ozyumenko \& Svetlana Kurteš (2017a). I-identity vs we-identity in language and discourse: Anglo-Slavonic perspectives. Lodz Papers in Pragmatics, 13 (1), 195-215.

Larina, Tatiana, Arto Mustajoki \& Ekaterina Protassova (2017b). Dimensions of Russian culture and mind. In Katja Lehtisaari \& Arto Mustajoki (eds.), Philosophical and Cultural Interpretations of Russian Modernisation, 7-19. London / New York: Routledge. 
Leech, Geoffrey N. (1983). Principles of Pragmatics. New York: Longman.

Leech, Geoffrey N. (2005). Politeness: Is there an East-West Divide? Journal of Foreign Languages, $6,1-30$.

Leech, Geoffrey N. (2014). The Pragmatics of Politeness. Oxford: Oxford University Press.

Leech, Geoffrey N. \& Tatiana Larina (2014). Politeness: West and East. Russian Journal of Linguistics, $4,9-34$.

Linguistic Politeness Research Group (ed.) (2011). Discursive Approaches to Politeness. Berlin: de Gruyter Mouton.

Locher, Miriam A. (2004). Power and Politeness in Action: Disagreements in Oral Communication. Berlin: Mouton de Gruyter.

Locher, Miriam A. (2006). Polite Behavior within Relational Work: The Discursive Approach to Politeness. Multilingua: Journal of Cross-Cultural and Interlanguage Communication, 25 (3), 249-267. doi: http://dx.doi.org/10.1515/MULTI.2006.015.

Locher, Miriam A. (2008). Relational work, politeness and identity construction. In Gerd Antos, Eija Ventola \& Tilo Weber (eds.). Handbooks of Applied Linguistics. Volume 2: Interpersonal Communication, 509-540. Berlin / New York: Mouton de Gruyter.

Locher, Miriam A. (ed.) (2010). Special issue: Politeness and impoliteness in computer-mediated communication Journal of Politeness Research, 6 (1), 1-150.

Locher, Miriam A. (2012). Politeness research from past to future, with a special focus on the discursive approach. In Lucía Fernández-Amaya, Maria de la O., Hernandez Lopez, Reyes Gomez Moron, Manuel Padilla Cruz, Manuel Mejias Borrero, \& Mariana Relinque Barranca (eds.). New Perspectives on (Im)Politeness and Interpersonal Communication, 36-60. Cambridge: Cambridge Scholars Publishing.

Locher, Miriam A. (2014). The relational aspect of language: Avenues of research. In Silvia Mergenthal \& Reingard M. Nischik (eds.). Anglistentag 2013 Konstanz: Proceedings, 309-322. Trier: Wissenschaftlicher Verlag Trier.

Locher, Miriam A. (2015). Interpersonal Pragmatics and its link to (im)politeness research. Journal of Pragmatics, 86, 5-10. doi: http://dx.doi.org/10.1016/j.pragma.2015.05.010.

Locher, Miriam A. (2017). Reflective Writing in Medical Practice. A Linguistic Perspective. Bristol: Multilingual Matters.

Locher, Miriam A. (2018). Politeness. In Carol A. Chapelle (ed.). The Encyclopedia of Applied Linguistics, 1-5. Hoboken: John Wiley \& Sons.

Locher, Miriam A., Brook Bolander \& Nicole Höhn (eds.). (2015). Special issue: Relational Work in Facebook and Discussion Boards/Fora. Pragmatics, 25, 1-122.

Locher, Miriam A. \& Sage L. Graham (2010). Introduction to Interpersonal Pragmatics. In Miriam A. Locher \& Sage L. Graham (eds.). Interpersonal Pragmatics, 1-13. Berlin: Mouton.

Locher, Miriam A. \& Martin Luginbühl (2019). Meta-discussions on Swiss and German politeness in online sources. In Eva; Ogiermann \& Pilar Garcés-Conejos Blitvich (eds.). From Speech Acts to Lay Understandings of Politeness: Multilingual and Multicultural Perspectives, 250 279. Cambridge: Cambridge University Press.

Locher, Miriam A. \& Richard J. Watts (2005). Politeness theory and relational work. Journal of Politeness Research, 1 (1), 9-33.

Locher, Miriam A. \& Richard J. Watts (2008). Relational work and impoliteness: Negotiating norms of linguistic behaviour. In Derek Bousfield \& Miriam A. Locher (eds.). Impoliteness in Language. Studies on its Interplay with Power in Theory and Practice, 77-99. Berlin: Mouton de Gruyter. 
Mills, Sara (2017). English Politeness and Class. Cambridge: Cambridge University Press.

Milroy, Lesley (1987). Language and Social Networks. New York: Blackwell.

Morgan, Marcyliena H. (1991). Indirectness and interpretation in African-American women's discourse. Pragmatics, 1 (4), 421- 451.

Paternoster, Annick \& Susan Fitzmaurice (eds.). (2019). Politeness in Nineteenth-Century Europe (Vol. 299). Amsterdam: John Benjamins.

Rathmayr, Renate (2003). The Pragmatics of Apology: A Comparative Study on the Material of the Russian Language and Russian Culture / Transl. from German by E. Aralova. Moscow: Yazyki slavyanskoy kul'tury (In Russian)

Rahmayr, Renate (2009). "New Russian politeness" - a fashion of business etiquette or a radical pragmatic change? Voprosy Jazykoznanija, 2009, 1, 63-81.

Rhee, Seongha \& Koo, Hyun Jung (2017). Audience-blind sentence-enders in Korean: A discoursepragmatic perspective. Journal of Pragmatics, 120, 101-121. doi: http://dx.doi.org/ 10.1016/j.pragma.2017.09.002.

Rosen, Devan, Pascale R. Lafontaine \& Blake Hendrickson (2011) CouchSurfing: Belonging and Trust in a Globally Cooperative Online Social Network. New Media \& Society, 13(6), 981—998.

Sharonov (ed.) Politeness and impoliteness in language and communication. Moscow: ROSPEN.

Sifianou, Maria (1992). Politeness Phenomena in England and Greece. Oxford, NY: Oxford University Press.

Sifianou, Maria \& Garcés-Conejos Blitvich, Pilar. (2018). Introduction: Im/politeness and globalisation. Journal of Pragmatics, 134, 113 - 119. doi: 10.1016/j.pragma.2018.06.014.

Spencer-Oatey, Helen (2005). (Im)Politeness, face and perceptions of rapport: Unpackaging their bases and interrelationships. Journal of Politeness Research, 1 (1), 95-119.

Spencer-Oatey, Helen (2009). Face, identity and interactional goals. In Francesca Bargiela Chiappini (ed.). Face, communication and social interaction, 137-155. London: Equinox.

Taavitsainen, Irma \& Andreas H. Jucker (2010). Trends and developments in historical pragmatics. In Andreas H. Jucker \& Irma Taavitsainen (eds.). Historical Pragmatics, 3-30. Berlin, New York: Mouton de Gruyter.

van Dijk, Teun A. (1998) Ideology: A Multidisciplinary Approach. London: Sage.

van Dijk, Teun A. (2006a) Ideology and discourse analysis. Journal of Political Ideologies, $11(2), 115-140$.

van Dijk, Teun A. (2006b) Politics, ideology and discourse. In Wodak R. (ed.) Encyclopedia of Language and Linguistics, Volume on Politics and Language, 728-740. Amsterdam: Elsevier.

Vásquez, Camilla (2011). Complaints online: The Case of TripAdvisor. Journal of Pragmatics, 43 (6), 1707-1717. https://doi.org/10.1016/j.pragma.2010.11.007.

Vásquez, Camilla (2014). 'Usually not one to complain but...': constructing identities in user-generated online reviews. In Philip Seargeant \& Caroline Tagg (eds.), The Language of Social Media, 65-90. Houndmills, Basingstoke: Macmillan. https://doi.org/10.1057/9781137029317_4.

Watts, Richard J. (2003). Politeness. Cambridge: Cambridge University Press.

Zemskaya, Elena A. (1997). Category of politeness: General Issues - Cultural Specifics of the Russian Language. Zeitschrift für slavische Philologie. Band LVI (1997). Heft 2, 271-301. (In Russ.)

Zhel'vis, Vladimir I. (2001/1997). Battlefield: Foul language as a social problem in the languages and cultures of the world. 2-nd ed. Moscow: Ladomir Publ. (In Russ.)

Zhel'vis, Vladimir I. (2014). Linguistic and cultural analysis of the dichotomy 'dicent-indicent' in English and Russian. Russian Journal of Linguistics, 4, 101-118. (In Russ.) 
Брагина Н.Г. Вежливость как невежливость: на стыке разных культурных норм и правил // Вежливость и антивежливость в языке и коммуникации / отв. ред. И.А. Шаронов. М.: РОССПЭН, 2018. С. 38-44.

Жельвис В.И. Поле брани. Сквернословие как социальная проблема в языках и культурах мира. М.: Ладомир, 2001/1997.

Жельвис В.И. Лингвокультурологический анализ дихотомии «прилично - неприлично» в англоязычных и русской культурах. Russian Journal of Linguistics. 2014. № 4. С. 101-118.

Земская Е.А. Категория вежливости: общие вопросы - национально-культурная специфика русского языка // Zeitschrift für slavische Philologie. Band LVI (1997). Heft 2. C. 271-301.

Ларина Т.В. Категория вежливости в английской и русской коммуникативных культурах: М.: Изд-во РУДН, 2003. 315 с.

Ларина Т.В. Концепт «вежливость» в коммуникативном сознании русских и англичан // Człoviek Świadomość Komunikacja Internet. Redakcja naukova L. Szypielevicz. Warszawa, 2004. C. 284-293.

Ларина Т.В. Категория вежливости и стиль коммуникации: Сопоставление английских и русских лингвокультурных традиций. М.: Языки славянских культур, 2009. 512 с. (Язык. Семиотика. Культура) Ларина Т.В. Англичане и русские: Язык, культура, коммуникация. М.: Языки славянских культур, 2013. 360 с.

Ларина Т.В., Харлова М.Л. Невежливость и грубость в межличностном общении американцев // Вестник Новосибирского государственного университета. Серия Лингвистика и межкультурная коммуникация. 2015. Том 13, вып. 3. С. 34-42.

Ратмайр Р. Прагматика извинения: Сравнительное исследование на материале русского языка и русской культуры / пер. с нем. Е. Араловой. М.: Языки славянской культуры, 2003.

Ратмайр Р. «Новая русская вежливость» - мода делового этикета или коренное прагматическое изменение? // Вопросы языкознания. 2009. № 1. С. 63-81.

Харлова М.Л. Концептуализация невежливости в русском и английском языках. Russian Journal of Linguistics. 2014. № 4. С. 119-131.

Харлова М.Л. Эмоции в невежливо и грубой коммуникации Russian Journal of Linguistics. 2015. № 3. С. $84-98$.

Шаронов И.А. (ред.) Вежливость и антивежливость в языке и коммуникации. М.: РОСПЭН, 2018.

\section{Bionotes:}

MIRIAM A. LOCHER is Professor of the Linguistics of English at the University of Basel. She teaches in the BA/MA English, the MA Language and Communication and is a member of the Eucor Hermann-Paul School of Linguistics for PhD students. Her research is on interpersonal pragmatics, linguistic politeness, relational work, the exercise of power, disagreements, advice-giving (in health contexts), computer-mediated communication, as well as online fan translations of politeness in Korean TV dramas into lingua franca English. Her publications comprise monographs, edited collections and special issues as well as a numerous articles in journals and collections.

Website: https://english.philhist.unibas.ch/en/persons/miriam-locher/profile/

Contact information: Miriam.locher@unibas.ch

TATIANA V. LARINA is Full Professor at RUDN University, the Editor-in-Chief of the Russian Journal of Linguistics. She has undergone training and conducted research in Ireland (Centre for Languages and Communication Studies of Trinity College) and given lectures as a visiting professor in India, Finland, Kazakhstan, and Italy. Her research interests embrace language, culture and communication; cross-cultural pragmatics, intercultural communication, communicative ethnostyles, and 
(im)politeness theory with the focus on English and Russian languages. She has authored and coauthored over 200 publications in Russian and English including monographs, course books, book chapters as well as a numerous articles.

Contact information: larina-tv@rudn.ru

\section{Сведения об авторах:}

МИРИАМ А. ЛОХЭР — профессор лингвистики Базельского университета, Швейцария. Преподает английский язык и коммуникацию студентам бакалавриата и магистратуры, а также работает в лингвистической школе Eucor Hermann-Paul для аспирантов. Сфера ее научных интересов - межличностная прагматика, теория вежливости, реляционная работа, проявление власти, выражение несогласия и совета, коммуникация в сфере здравоохранения, компьютерная коммуникация, английский язык как lingua franca. Среди ее публикаций - монографии, главы книг и многочисленные статьи, также она является редактором сборников и специальных выпусков ведущих лингвистических журналов.

Веб-сайm: https://english.philhist.unibas.ch/en/persons/miriam-locher/profile/

Контактная информация: Miriam.locher@unibas.ch

ТАТЬЯНА ВИКТОРОВНА ЛАРИНА — профессор Российского университета дружбы народов (РУДН), главный редактор журнала Russian Journal of Linguistics. Проходила научную стажировку в Центре изучения языков и коммуникации Тринити колледжа (Ирландия), в качестве приглашенного профессора читала лекции в Индии, Финляндии, Казахстане и Италии. Ее исследовательские интересы охватывают лингвокультурологию, кросс-культурную прагматику, межкультурную коммуникацию, коммуникативную этностилистику и теорию не/вежливости. Она является автором и соавтором более 200 публикаций на русском и английском языках, включая монографии, учебники, главы книг, а также многочисленные статьи.

Контактная информация: larina-tv@rudn.ru 